\title{
WORKING CAPITAL MANAGEMENT AND FIRM VALUE IN EMERGING MARKETS: THE CASE OF SRI LANKA
}

\author{
Pratheepkanth Puwanenthiren
}

University of Jaffna, Sri Lanka

\begin{abstract}
Working capital management, which involves managing cash, inventory, and accounts receivable, affects a firm's short-term attainment. The purpose of this paper is to seek to investigate the relationship between working capital management and firm value in Sri Lankan firms. Data from 100 Sri Lankan firms a period of five years (2014-2018) are used for this purpose and analysed using the regression technique. The results indicate that there is a strong positive relation between the firm's cash conversion cycle, number of day's account payable and firm size and its firm value. Although, number of day's account receivable and number of day's inventory are found to be significant with negative sign. Overall the results imply that the Sri Lankan firms need to concentrate their limited resources on managing cash conversion cycle in order to be improve firm value
\end{abstract}

Keywords: Working capital, Cash conversion cycle, Firm value

\section{Introduction}

The traditional focus in corporate finance was on the long-term financial decisions such as capital budgeting, capital structure and dividend (Nobanee, Abdullatif, \& AlHajjar, 2011). While, working capital management is of importance to all firm size operating in both developed and emerging countries, working capital management is of particular importance to the business firm operating in emerging markets (Abuzayed, Working capital management and firms' performance in emerging markets: the case of Jordan, 2012). Firms in emerging markets are mostly small in size with limited access to the long-term capital markets. These firms tend to rely more heavily on owner financing, trade credit and short-term bank loans to finance their needed investment in cash, accounts receivable and inventory (Chittenden, Poutziouris, \& Michaelas, 1998; Saccurato, 1994). Given the significant investment in working capital and the effect of working capital policy on firm risk in most firms, working capital policy choices ad practices could have important implications not only for accounting profitability but also for firm value. Many studies have been published with the aim of establishing relations between WCM and profitability. Most of them have found a negative relationship between profitability and cash conversion cycle - which represents the length of time between the acquisition of raw materials and other inputs and the inflow of cash from the sale of goods, and reflects the decisions on the amount invested in inventory, loans to customers and credit obtained from suppliers - pointing to the idea that the practice of an aggressive policy of working capital management tends to improve corporate profitability (Jose, Lancaster, \& Stevens, 1996; Lazaridis \& Tryfonidis, 2006; Juan-García-Teruel \& Martinez-Solano, 2007; Falope \& Ajilore, 2009). The firm value is a long term measure of performance (Samiloglu \& Demirgunes, 2008). Since working capital is within a firm control and independent macro economic factors, it allows a firm to adapt to changing econmic envirnment easily and enahnce its economic value added (Falope \& Ajilore, 2009). The efficient management of working capital helps helps increase free cash flows used to value a firm, thus maximizing firm 
value (Berk, et al., 2013). As such, the main research question is what is the association between WCM and firm value within Sri Lanka? While most of WCM studies focus on developed countries, there is an increasing interest in WCM in developing countries (Ching, Novazzi, \& Gerab, 2011). Sri Lanka has recently experienced rapid economic growth after emerging from decades of civil war. While Sri Lanka's recent economic reforms are potentiating the gains from peace, Sri Lanka is still an emerging country with gaps in its development and market regulations. The purpose of this paper,

\section{Review of Literature}

Working capital management is of importance to all firms operating in both developed and emerging countries, working capital management is of particular importance to the business firms operating in emerging markets (Chttenden, Poutziouris, \& Michaelas, 1998; Sccurato, 1994). Firms in emerging markets are mostly small in size with limited access to the long-term capital markets. These firms tend to rely more heavily on owner financing, trade credit and short-term bank loans to finance their needed investment in cash, accounts receivable and inventory (Abuzayed, 2012). Working capital management is a significant area of finance, and the administration of working capital may have an important impact on the profitability and liquidity of the firm (Gill, Biger, \& Mathur, 2010). Firms can choose between the relative benefits of two basic types of strategies for net working capital management: they can minimize working capital investment or they can adopt working capital policies designed to increase sales. Thus, the management of a firm has to evaluate the trade-off between expected profitability and risk before deciding the optimal level of investment in current assets. Previous studies have shown that weak financial management - particularly poor working capital management and inadequate long-term financing - is a primary cause of failure among small businesses (Berryman, 1983; Dunn \& Cheatham, 1993; Ching, Novazzi, \& Gerab, 2011). Ghosh and Maji (2004) made an empirical study on the relationship between utilization of current therefore, is to investigate the relation between WCM and form value for Sri Lankan firms listed on the Colombo Stock Exchange (CSE) for different firm sizes and for firms from different industries.

This paper is organised as follows: Section 1.2 presents a review of the empirical studies that investigate the association between WCM and firm value; Section 1.3 addresses research methods; Section 1.4 reports the results and discussion; and Section 1.5 summarises the conclusion.

assets and operating profitability in the Indian cement and tea industry. The study concluded that the degree of utilization of current assets was positively associated with the operating profitability of all the companies under study. Vijayakumar and Venkatachalam, (1995) and Mallik, Sur, and Rakshit (2005) noticed that the joint influence of the liquidity, inventory management and credit management on the profitability were statistically very significant in nine out of 17 companies selected for the study. Zariyawati, Annuar, Taufiq, and Rahim (2009) study the relationship between profitability and the length of the cash conversion cycle using six different economic sectors which are listed in Bursa Malaysia. Their analysis provide a strong negative significant relationship between cash conversion cycle and firm profitability. Deloof (2003) who revealed negative relationship between profitability and number of days accounts receivable, inventories and accounts payable of Belgian firms for the period 1992-1996. In addition, collecting receivables quickly involves other negative effects like high transaction cost of converting receivables back into cash (Kim \& Atkins, 1978), default risk (Shi \& Zhang, 2010) and proves determinant in patronizing company's products. With regard to accounts payable, it is argued that firm may obtain important discounts for early payments when it reduces its supplier financing (Wilner, 2000). Supporting the above literature, positive impact of cash converstion cycle on firm performance has been supported by a 
number of empirical studies (Bhunia \& Das, 2015; Martínez-Sola, García-Teruel, \& Martínez-Solano, 2013; Sharma \& Kumar, 2011). Apart from the common findings of negative associations of profitability with working capital, there have been numerous research studies where higher working capital has been favored for firms' health.

According to Deloof (2003), higher level working capital levels provide the firms an opportunity to improve sales and negotiate for lower costs of raw materials by availing extra discounts by shortening payment cycle. Panda (2012) analyzed the sales pattern relative to working capital (both gross as well as net) across firms in paper sector in India and reported appreciation in gross working capital to result in higher sales. Contrary to results of many other studies, the analysis undertaken by Abuzayed (2012) elucidated profitability to be positively correlated with cash coversition cycle for firms of Amman Stock Exchange. This implies that reducing working capital investment is likely to lead to higher profits.

Another point that emerges from the literature review is that the relationship has been tested in various markets but no empirical evidence is available for the emerging economy of Sri Lanka. This motivates to explore the nature of relationship between working capital management and firm value of Sri Lankan firms, which forms the basis of the study. In the way, this paper aims at contributing to our knowledge by studying the working capital management and its relation to firm value in a different context, Sri Lanka. As the
Sri Lanka business environment is relatively different from that of other top economies of the world, it is interesting to examine whether the characteristics of the Sri Lankan firm might have an effect on their working capital management and therefore their firm value.

\section{Methodology}

The population of interest in this study is (initially) the 295 listed firms on the CSE, as at February 2014. This study excludes financial, investment and securities sector firms because their unique financial attributes, intensity of regulation, and/or intensive use of leverage are likely to confound the outcomes being studied. Also, the risk of missing data was minimised by excluding firms that were not listed throughout the review period. After the eliminations 100-firmssample, randomly drawn from the exchange -listed firms (Saunders et al. 2009), was analysed.

The sources of the data were the 2014/18 financial reports. The financial reports were chosen for two reasons (Bozzolan, Favotto, \& Ricceri, 2003; Lang \& Lundholm, 1993) such as they are considered an important source of firm information by external users and the disclosure level in financial reports is positively correlated with amount of corpoarte information communicated to the market and to stakeholders using other media. In independent variables, cash conversion cycle, number of day's account receivable, number of day's inventory and number of day's account payable are used to measure WCM.

Table 01: Varaible measurement

\begin{tabular}{|c|c|c|}
\hline Variable & Measurement & Source \\
\hline \multicolumn{3}{|c|}{ Dependent variables } \\
\hline Firm value & $\begin{array}{l}\text { Firm's common stock price * shares outstanding at the end } \\
\text { of the fiscal year } t \text { (or its market capitalisation) + preferred } \\
\text { stock (taken to be, in order and as available, redemption } \\
\text { value liquidating value or par value) + total book liabilities } \\
- \text { deferred tax and investment tax credit) if available. }\end{array}$ & $\begin{array}{c}\text { (Fama \& } \\
\text { French, } \\
\text { 1998) }\end{array}$ \\
\hline \multicolumn{3}{|c|}{ Independent variables } \\
\hline $\begin{array}{l}\text { Cash conversion } \\
\text { cycle }\end{array}$ & $\begin{array}{l}\text { Number of day's account receivable }+ \text { number of days } \\
\text { inventory - number of day's accounts payable }\end{array}$ & $\begin{array}{c}\text { (Abuzayed, } \\
2012 \text { ) }\end{array}$ \\
\hline
\end{tabular}




\begin{tabular}{|l|l|c|}
\hline $\begin{array}{l}\text { Number of day's } \\
\text { account } \\
\text { receivable }\end{array}$ & Accounts receivable / sales *365 & $\begin{array}{c}\text { (Abuzayed, } \\
2012)\end{array}$ \\
\hline $\begin{array}{l}\text { Number of day's } \\
\text { inventory }\end{array}$ & Inventories / cost of sales *365 & $\begin{array}{c}\text { (Abuzayed, } \\
2012)\end{array}$ \\
\hline $\begin{array}{l}\text { Number of day's } \\
\text { account payable }\end{array}$ & Accounts payable / purchases *365 & $\begin{array}{c}\text { (Abuzayed, } \\
2012)\end{array}$ \\
\hline \multicolumn{2}{|c|}{ Control variables } & $\begin{array}{c}\text { (Abuzayed, } \\
2012)\end{array}$ \\
\hline Firm size & The natural logarithm of sales &
\end{tabular}

\section{Results and Discussion}

The descriptive statistics for the study variables are depicted in Table 02. The average cash conversion cycle is 154.98 days. With regard to the average number of days of accounts receivable (130.93), as receive payment on sales after this time, this result indicates that the collection of sales can take too long. The average number of days of accounts inventories is 93.54, showing that most Sri Lankan firms take 93.54 days to sell their products, while the number of days of accounts payable is 69.81 , potentially indicating a generous policy of trade credit. Also in these tabled results, firm size is at around 11.876 percent.

Table 02: Descriptive analysis

\begin{tabular}{|l|c|c|c|c|}
\hline \multicolumn{1}{|c|}{ Variable } & Mean & SD & Minimum & Maximum \\
\hline Cash conversion cycle & 154.980 & 154.645 & -18.783 & 644.121 \\
\hline Number of day's account receivable & 130.930 & 128.804 & 7.099 & 648.113 \\
\hline Number of day's inventory & 93.540 & 132.721 & 21.630 & 587.658 \\
\hline Number of day's account payable & 69.814 & 93.602 & 0.045 & 439.565 \\
\hline Firm size & 11.876 & 20.622 & -43.073 & 98.303 \\
\hline Firm value & 11.951 & 22.427 & -60.191 & 81.499 \\
\hline
\end{tabular}

Table 03 presents Pearson correlation coefficients for all variables considered in this study. As these results indicate, there is a positive relationship between cash conversion cycle and the firm value, as insignificance is at the 0.01 level. The relationship between number of day's account receivable and the firm value is also insignificance.

In addition, the association between cash conversion cycle and number of day's account receivable is positive at the 0.01 ; number of day's inventory is significant $\left(0.774^{* *}\right)$; number of day's account payable is significant $\left(0.296^{*}\right)$.

The correlation between number of day's inventory, number of day's account payable and firm value is positive and insignificant at the 0.01 level. The positive sign of correlation between firm size and firm value at the 0.001 level $\left(0.903^{* *}\right)$ indicates a positive relationship; thus, an increase in the firm size will likely lead to an increase in firm value. 
Table 03: Correlation analysis

\begin{tabular}{|c|c|c|c|c|c|c|}
\hline & $\mathbf{C C C}$ & ARD & ID & APD & Size & Fvalue \\
\hline CCC & 1 & & & & & \\
\hline \multirow[t]{2}{*}{ ARD } & $.620 * *$ & \multirow[t]{2}{*}{1} & & & & \\
\hline & .000 & & & & & \\
\hline \multirow[t]{2}{*}{ ID } & $.774^{* *}$ & .208 & \multirow[t]{2}{*}{1} & & & \\
\hline & .000 & .074 & & & & \\
\hline \multirow[t]{2}{*}{ APD } & $.296^{*}$ & $.646^{* *}$ & $.423^{* *}$ & \multirow[t]{2}{*}{1} & & \\
\hline & .010 & .000 & .000 & & & \\
\hline \multirow[t]{2}{*}{ Size } & .051 & .217 & -.019 & .188 & \multirow[t]{2}{*}{1} & \\
\hline & .663 & .061 & .873 & .106 & & \\
\hline \multirow[t]{2}{*}{ Fvalue } & .057 & .195 & -.155 & .146 & $.903^{* *}$ & \multirow[t]{2}{*}{1} \\
\hline & .628 & .094 & .184 & .212 & .000 & \\
\hline
\end{tabular}

To assist in answering this study's research questions, a standard multiple regression analysis was used. The outputs of this regression analysis can be found in Table 04 .

Table 04: Regression results

\begin{tabular}{|l|c|}
\hline & $\begin{array}{c}\text { Model } \\
\text { Firm Value }\end{array}$ \\
\hline Constant & 0.984 \\
\hline Cash conversion cycle & $(0.329)$ \\
\hline & 2.180 \\
\hline $\begin{array}{l}\text { Number of day's account } \\
\text { receivable }\end{array}$ & -2.175 \\
\hline & $(0.033)$ \\
\hline Number of day's inventory & -2.250 \\
\hline & $(0.028)$ \\
\hline $\begin{array}{l}\text { Number of day's account } \\
\text { payable }\end{array}$ & 2.203 \\
\hline & $(0.031)$ \\
\hline Firm size & 18.234 \\
\hline R & $(0.000)$ \\
\hline Adjusted R Square & 0.920 \\
\hline F & 0.835 \\
\hline Sig & 75.980 \\
\hline
\end{tabular}

The model adjusted $\mathrm{R}^{2}$ value of firm value indicate that 0.835 percent of the observed variability in firm value can be explained by the working capital management. The Fstatistics and significance level (Table 3) shows that firm value model generate statistically significant outcomes. Cash conversion cycle is significant at least at 5 percent level while number of day's account receivable and number of day's inventory are found to be significant with negative sign. Number of day's account payable has a positive and significant effect on firm value. Firm size is highly significant on firm value at the 1 percent level.

\section{Concluding Remarks}

Increased competition in recent decades has directed attention to the rationalization of short-term investments, giving working capital management a crucial role in firm profitability/value (Jose, Lancaster, \& Stevens, 1996; Shin \& Soenen, 1998; Lazaridis \& Tryfonidis, 2006). The findings of the study is consistent with studies conducted by Abuzayed (2012); Teruel and Martinez (2007); Wasiuzzaman (2015). However, the findings diverge from Nobanee, Abdullatif, and AlHajjar (2011) who observed that a strong negative relation between the length of the firm's cash conversion cycle and its profitability. The results of this study document that cash conversion cycle is significant at least at the 5 percent level. This finding is consistent with studies by Peel, Wilson, and Howorth (2000) and Ebben and Johnson (2011) who disclose that efficient cash conversion cycle management gives managers better control over a firm's short-term investments, which in turn may affect risk, profitability, and thereby firm value but contrary to a study by Mathuva (2010), reveals that there was a highly significant negative relationship between CCC and firm profitability. 
Whilst, number of day's account receivable and number of day's inventory are found to be significant with negative sign. This result in this study are comparable study by: Deloof (2003) analyzes a sample of large Belgian firms during the period 1992-1996. His results confirm that Belgian firms can improve their profitability by reducing the number of days accounts receivable are outstanding and reducing inventories. The findings of this study note that number of day's account payable has a positive and significant effect on firm value. Firm size is highly significant on firm value at the 1 percent level. The results are similar to those found in previous studies that focused on large firms (Abuzayed, 2012; Deloof, 2003; Falope \& Ajilore, 2009) and the analyses carried out confirm the important role of working capital management in value generation in the firms.

\section{Limitation and further research}

A key limitation in this study flows from the difficulties inherent in discovering and adjusting for variations in the working capital management, business scope, and/or financing portfolio across firms. Like most previous studies, this study examined only selected proxies for firm value. Difficulties arising from accounting standards and principles differing between countries were greatly mitigated over the past decade by the spread of International Financial Reporting Standards (IFRS).

Future research should consider including many countries. The effect of working capital management on firm value should be more fully examined in future research. Such research might best be a study "jointly and severally" across a range of developed and emerging nations. In addition, future research might expand its consideration to include the influence of socio-economic factors and human capital on working capital management.

\section{Reference}

Abuzayed, B. (2012). Working capital management and firms' performance in emerging markets: the case of Jordan. International Journal of Managerial Finance, 8(2), 155-179.

Abuzayed, B. (2012). Working capital management and firms' performance in emerging markets: the case of Jordan. International Journal of Managerial Finance, 8(2), 155-179.

Berk, J., DeMarzo, P., Harford, J., Ford, G., Mollica, V., \& Finch, N. (2013). Fundamentals of corporate finance. Boston : Pearson .

Berryman, J. (1983). Small business failure and survey of the literature. European Small Business Journal, 1(4), 47-59.

Bhunia, A., \& Das, A. (2015). Underlying relationship between working capital management and profitability of pharmaceutical companies in India. American Journal of Theoretical and Applied Business, 1(1), 27-36.

Ching, H., Novazzi, A., \& Gerab, F. (2011). Relationship between working capital management and profitability in Brazilian listed companies. Journal of Global Business and Economics, 3(1), 74-86.

Chittenden, F., Poutziouris, P., \& Michaelas, N. (1998). Financial management and working capital practices in UK SMEs. Manchester: Manchester Business School.

Chttenden, F., Poutziouris, P., \& Michaelas, N. (1998). Financial management and working capital practices in UK SMEs. Manchester: Manchester Business School.

Deloof, M. ".-4.-5. (2003). Does working capital management affect profitability of Belgian firms? Journal of Business Finance \& Accounting, 30(3-4), 573588.

Dunn, P., \& Cheatham, L. (1993). Fundamentals of small business financial management for start up, survival, growth, and changing economic circumstances. Managerial Finance, 19(8), 1-13. 
Ebben, J., \& Johnson, A. (2011). Cash conversion cycle management in small firms: Relationships with liquidity, invested capital, and firm performance. Journal of Small Business \& Entrepreneurship, 24(3), 381-396.

Falope, O., \& Ajilore, O. (2009). Working capital management and corporate profitability: evidence from panel data analysis of selected quoted companies in Nigeria. Research Journal of Business Management, 3(3), 73-84.

Fama, E., \& French, K. (1998). Taxes, financing decisions, and firm value. The Journal of Finance, 53(3), 819843.

Ghosh, D., \& Maji, S. (2004). Working capital management efficiency: A study on the Indian cement industry. Management Accountant, 39, 363-372.

Gill, A., Biger, N., \& Mathur, N. (2010). The relationship between working capital management and profitability: Evidence from the United States. Business and Economics Journal, 10(1), 1-9.

Jose, M., Lancaster, C., \& Stevens, J. (1996). Corporate returns and cash conversion cycles. Journal of Economics and Finance, 1, 33-50.

Juan-García-Teruel, P., \& Martinez-Solano, P. (2007). Effects of working capital management on SME profitability. International Journal of Managerial Finance, 3(2), 164-177.

Kim, Y., \& Atkins, J. (1978). The Journal of Finance. Evaluating investments in accounts receivable: $a$ wealth maximizing framework, 33(2), 403412.

Lazaridis, I., \& Tryfonidis, D. (2006). Relationship between working capital management and profitability of listed companies in the Athens Stock Exchange. Journal of Financial Management and Analysis, 19(1), 2638.
Mallik, A., Sur, D., \& Rakshit, D. (2005). Working capital and profitability: a study on their relationship with reference to selected companies in Indian pharmaceutical industry. GITAM Journal of Management, 3(2), 51-62.

Martínez-Sola, C., García-Teruel, P., \& Martínez-Solano, P. (2013). Corporate cash holding and firm value. Applied Economics, 45(2), 161-170.

Mathuva, D. (2010). The influence of working capital management components on corporate profitability: a survey on Kenyan listed firms. Research Journal of Business Management, 4(1), 1-11.

Nobanee, H., Abdullatif, M., \& AlHajjar, M. (2011). Cash conversion cycle and firm's performance of Japanese firms. Asian Review of Accounting, 19(2), 147-156.

Panda, A. (2012). The status of working capital and its relationship with sales: An empirical investigation of Andhra Pradesh Paper Mills Ltd (India). International Journal of Commerce and Management, 22(1), 36-52.

Peel, M., Wilson, N., \& Howorth, C. (2000). Late payment and credit management in the small firm sector: some empirical evidence. International Small Business Journal, 18(2), 17-37.

Pratheepkanth, P., Hettihewa, S., \& Wright, C. (2015). Capital budgeting practices in Australia and Sri Lanka: A comparative study. Global Review of Accounting and Finance, 6(2), 16-30.

Saccurato, F. (1994). The study of working capital. Business Credit, 96(2), 36-37.

Samiloglu, F., \& Demirgunes, K. (2008). The effect of working capital management on firm profitability: Evidence from Turkey. The International Journal of Applied Economics and Finance, 22(1), 44-50.

Sccurato, F. (1994). The study of working capital. Business Credit, 96(2). 
Sharma, A., \& Kumar, S. (2011). Effect of working capital management on firm profitability: Empirical evidence from India. Global Business Review, 12(1), 159-173.

Shi, X., \& Zhang, S. (2010). An incentivecompatible solution for trade credit term incorporating default risk. European Journal of Operational Research, 206(1), 178-196.

Shin, H., \& Soenen, L. (1998). Efficiency of working capital management and corporate profitability. Financial Practice and Education, 8, 37-45.

Teruel, P., \& Martinez, P. (2007). Effects of working capital management on SME profitability. International Journal of Managerial Finance, 3(2), 164-177.

Vijayakumar, A., \& Venkatachalam, A. (1995). Working capital and profitability-an empirical analysis. Management Accountant, 30, 748-750.

Wasiuzzaman, S. (2015). Working capital and firm value in an emerging market. International Journal of Managerial Finance, 11(1), 60-79.

Wilner, B. (2000). The exploitation of relationships in financial distress: The case of trade credit. The Journal of Finance, 55(1), 153-178.

Zariyawati, M., Annuar, M., Taufiq, H., \& Rahim, A. (2009). Working capital management and corporate performance: Case of Malaysia. Journal of Modern Accounting and Auditing, 5(11), 47-66. 